\title{
Concrete Structures' Quality Control in Practice
}

DOI 10.5592/otmcj.2011.1.8 Technical paper

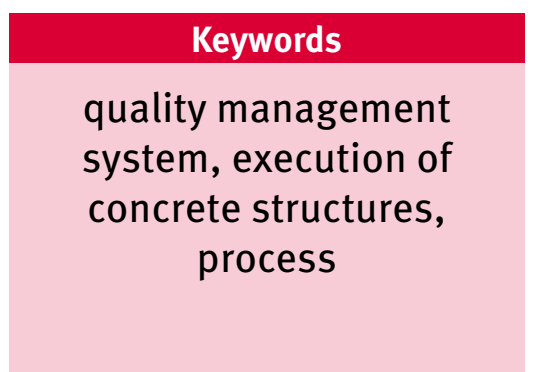

\author{
Zlata Dolaček-Alduk, PhD. \\ Josip Juraj Strossmayer University of Osijek \\ Faculty of Civil Engineering Osijek, Croatia \\ Email: zlatad@gfos.hr
}

The CRoAtian CIVIL ENGINEeRING IS CHARACTERIZEd BY A LACK OF SYSTEMATIC APPROACH TO PLANNING, CONTROL AND QUALITY ASSURANCE IN ALL PHASES OF PROJECT REALIZATION. The results obtained in establishing the quality management system in some segments of civil engineering production represent initial trends in solving this problem. Benefits are of two types: the achievement of quality for the contractor and obtaining that quaity is being achieved for clients. Execution of concrete structures is a complex process that includes various activities. The basic principle of the development and the application of quality management system during the execution of concrete structures is the process approach. Defining the processes, identification and interaction of sub-processes are performed with the objective of quality monitoring and control that are required in order to achieve concrete structures' specifications. Quality management system in the area of execution of concrete structures must also comply with national acts, rules, regulations and standards that are essential for concrete structures design, execution and concrete production.

Legal framework for quality assurance in execution of concrete structures in Croatia

Concrete works occupy a significant part of the execution phase in construction projects. Execution of concrete structures is a complex process that includes activities undertaken for the physical completion of a construction: planning and preparation of the entire process, scaffolding, formwork, reinforcement, concrete casting, its care and protection, installation elements, control and monitoring activities and documenting the process. The legal framework in Croatia, governing the execution of concrete structures and verifying compliance of concrete to specifications, consists of the following laws, regulations and standards:

- Physical Planning and Building Act (Official Gazette 76/07, 38/09)

- Act on Construction Products (Official Gazette 86/08)

- Act on Architectural and Engineering Activities in Physical Planning and Building (Official Gazette 152/o8) 
- Technical regulation for concrete structures, particularly Appendix A (Concrete) and Appendix J (Execution and maintenance of concrete structures) (Official Gazette 139/09, 14/10, 125/10)

- Ordinance on granting authorization for commencing with the performance of construction activities (Official Gazette 43/o9)

- Ordinance on technical approval for construction products (Official Gazette 103/08, 147/09, 87/10)

- HRN EN 13670:2010 Execution of concrete structures

- HRN EN 206-1:2006 Concrete Part 1: Specification, performance, production and conformity

- HRN 1128:2007 Concrete Guidelines for the implementation of HRN EN 206-1.

In recent years the concrete industry is constantly under pressure to improve productivity and reduce costs without lowering the standard of quality. The quality assurance system should be capable to reduce the number of nonconformities and provide means of detecting non-conformity when it has occurred. Also, quality assurance system should provide activities on tracking the origins of non-conformity. The documentation essential for the process of concrete structures execution must be consistent with the requirements of the standards HRN EN 13670 and HRN EN ISO 9001 and implemented into the quality management system in the company.

\section{Participants in the execution of concrete structures}

The direct participants in the execution of concrete structures are a manufacturer of concrete, a concrete contractor, a concrete construction engineer and a supervising engineer. In addition to the direct participants in the design of the concrete structures, in order to achieve the final quality of concrete, involvement of competent participants is necessary - an accredited laboratory and/or contractor laboratory. The obligation of all the participants in the process of execution of concrete structures is to meet legal and regulatory framework to achieve the required quality performance.

\section{Manufacturer of concrete}

The manufacturer of concrete is fully responsible for the concrete production, evaluation and certification of compliance. For this purpose, the manufacturer is obliged to implement the following activities:

- initial type testing for designed concrete

- factory production control (FPC)

- testing samples from production according to the established plan.

The composition of the concrete must be confirmed by examining the initial requirements of the standard HRN EN 206-1, Annex A. Concrete manufacturer is responsible for the initial type testing of the designed concrete. Initial test determines whether the concrete meets all the conditional properties of a fresh and hardened concrete. Before every use of a new composition of concrete, or in case of significant changes in component materials, the initial testing must be done.

Factory production control of the concrete is carried out according to the requirements of HRN EN 206-1, HRN 1128 and HRN EN ISO 9001, and should include all measures necessary to maintain and secure the properties of the concrete. This control includes all the checks and tests, using the results of testing the equipment, raw materials, fresh and hardened concrete. Documented production control system determines the responsibilities, authorizations and relationships of all staff that manages, executes and confirms the work related to the manufacture of concrete. This particularly applies to the staff that needs the organizational freedom and authority to minimize the risk of unsatisfactory concrete and to identify and report any problem with the quality of the concrete.

The manufacturer must ensure the following:

organize a permanent laboratory
and factory production control
appoint a person responsible
for implementing actions in
the procedure of conformity
assessment of products
establish a system of written
instructions to perform certain
actions in the procedure of
conformity assessment (quality
manual, procedures, work
instructions and records).

The manufacturer of concrete must carry out sampling and testing of fresh and hardened concrete as documented in the sampling plan of concrete plants, according to HRN EN 206-1 and HRN 1128. Tests can be conducted in a private or an accredited laboratory.

\section{Concrete contractor}

The contractor shall perform concrete work in accordance with the project, technical manufacturer's instructions for concrete casting and use of construction products and the technical regulation requirements for concrete structures. Control and supervision before and after the concrete casting is defined in the Technical regulations for concrete structures, Appendix J, and enforced by the supervising engineer and contractors' interior supervisor. Monitoring undertaken by the contractor is defined by the standard HRN EN 13670. Depending on the complexity of the construction and supervision rank, contractor shall appoint a responsible person who conducts internal control. The appointed person must meet the requirements of expertise, experience, independence and impartiality.

Before the application of the latest legal framework, concrete works 
contractor was required to submit a concrete design, consisting of the organization of concrete casting, composition, transport and necessary equipment, to the supervising engineer. Currently, the contractor must prepare a "Plan for Quality Performance" with the applicable quality management system on site. This plan includes plans of concrete casting and sampling and testing and it must be harmonized with the main project. The contractor is required to collect evidence on the testing of fresh and hardened concrete at the construction site and to keep records of the procedures carried out according to the quality control performance. Test samples can be done in the contactors' laboratories or in the independent accredited laboratories.

\section{Concrete construction engineer}

An essential prerequisite for the performance of concrete structures is the correct and detailed design documentation. The documentation should provide a basis for the quality and reliable performance. Construction engineer is responsible for the design of technical documentation - design of the concrete structure. According to the Technical Regulations for concrete structures, design of the concrete structure is an integral part of the building design that includes substantial technical descriptions, calculation of bearing capacity and usability and concrete structures' quality assurance and control program.

The standard HRN EN 13670 Design of concrete structures, Appendix A, provides information that designers must take into account during the design process. Depending on the terms and conditions of the construction, the requirements of the program control and quality assurance can be further developed in the concrete implementation project.

\section{Supervising engineer}

The supervisor is a person authorized to conduct the technical supervision of the construction on behalf of the investors. Supervising engineer carries out control measures following the design of the concrete structures and the given supervision rank. The control includes the supervision before the concreting, during the concreting and supervision after the concreting. In addition, supervising engineer cooperates on the implementation of measures from the quality plan and gives approval for the execution documentation of the contractor. These control procedures are implemented according to the plan for sampling and testing of concrete on site, done by the contractor and approved by the supervising engineer.

Supervising engineer performs the inspection activities for all the activities in the execution of the concrete structure that include:

- preparatory work (planning)

- scaffolding and formwork (before and after casting)

- valves (before and after the concrete)

- concrete (supervisory actions before casting, production, fresh concrete, installation and compaction, care and protection, surveillance operations after casting).

In addition to the monitoring activities during the performance of concrete construction, supervising engineer prepares a final report in which the supervising engineer also specifies the part on the implementation of the control procedures concerning conformity assessment.

By applying the process approach, the performance of concrete work can be summarized as follows (Figure 1) [1].

\section{Process approach - Concrete work performance}

Performance of concrete work is defined as a unique process that consists of a series of controlled and organized activities with start and end dates, conducted with the aim of reaching demands, including time, resources, quality and costs. Quality system in this process includes the organizational structure, documentation, activities and resources required to meet the requirements of the standard HRN EN 13670 and Annex J of the Technical regulations for concrete structures.

Performance of concrete work should be viewed and researched as a process of production or service delivery process. The process must be planned, established and controlled to ensure the concrete structure that meets the essential requirements. Input parameters are: the legislative and regulatory framework and the project documents, while the output parameter is the concrete structure delivered $n$ accordance with the input requirements. Elements of the system such as the person responsible for performing the process, materials, manufacturing technology, equipment and machinery, are the key elements in the process.

Application of the process approach in the execution of concrete work can be summarized as follows (Figure 2). All elements of the process are involved and feedback has been obtained through supervision.

Quality system in this process includes the following activities:

- analysis of the project documents

- drafting the operational plan

- developing the concrete structures quality performance plan

- preparation works

- erection of scaffolding and

formwork

- reinforcement assembly 


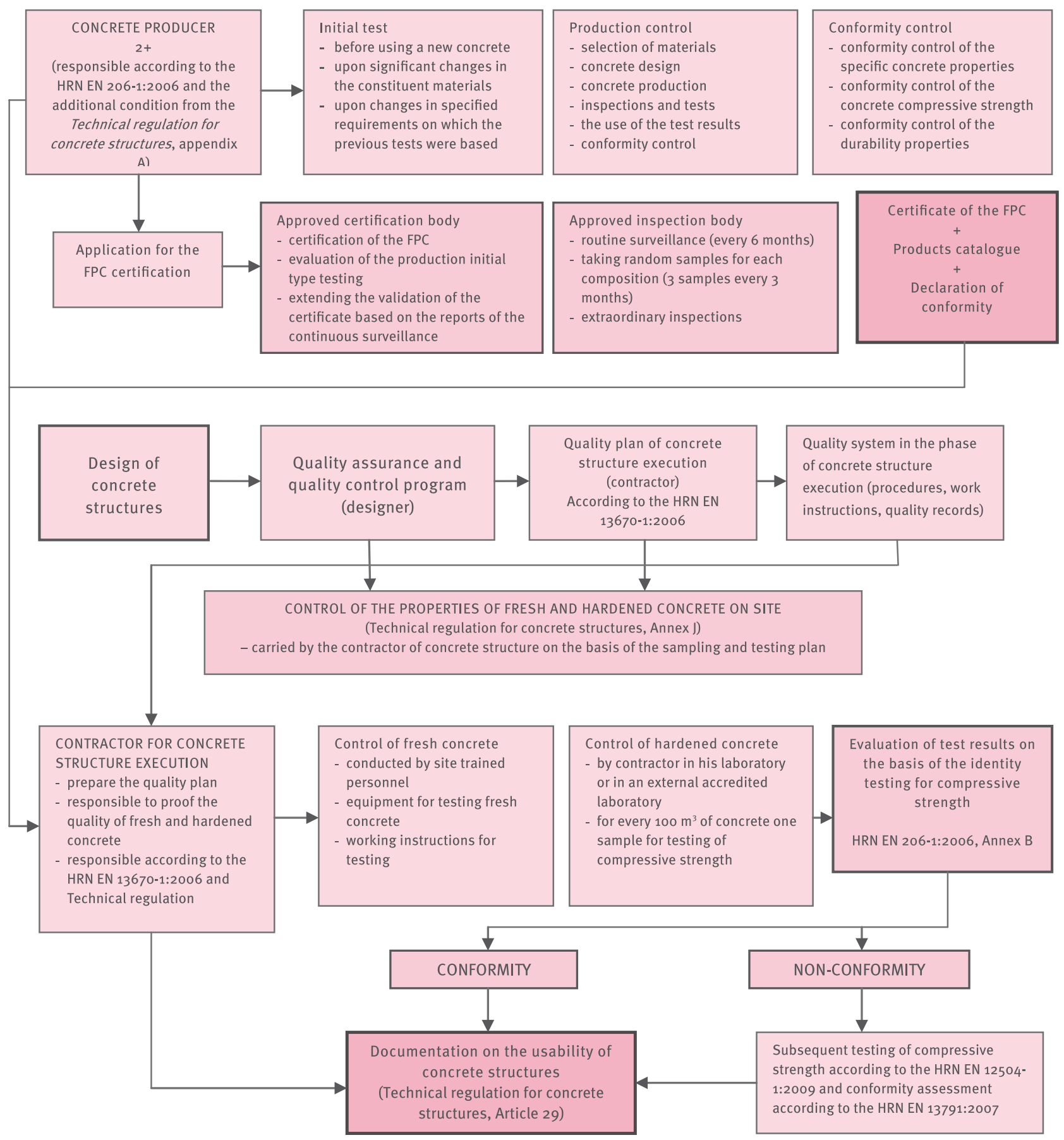

Figure 1: Example of the quality management in the execution of concrete structures

delivery, reception and site transport of concrete

- actions that are carried out before the concrete casting

- casting and compaction of concrete

- cultivation and protection of concrete

- actions to be carried out after the casting
- analysis and preparation of the reports on the procedures of conformity assessment of concrete with the project.

It is essential that those involved in the quality management system are familiar with the range of responsibilities, such as management administration, process owners and those directly involved in the activities performed. Over time, documents of the process performance have to be reviewed and revised to be fully harmonized with the practice. Changes in the documents and withdrawal of invalid documents will be done in accordance with the procedure for managing the documentation that defines the standard HRN EN ISO 9001. The 

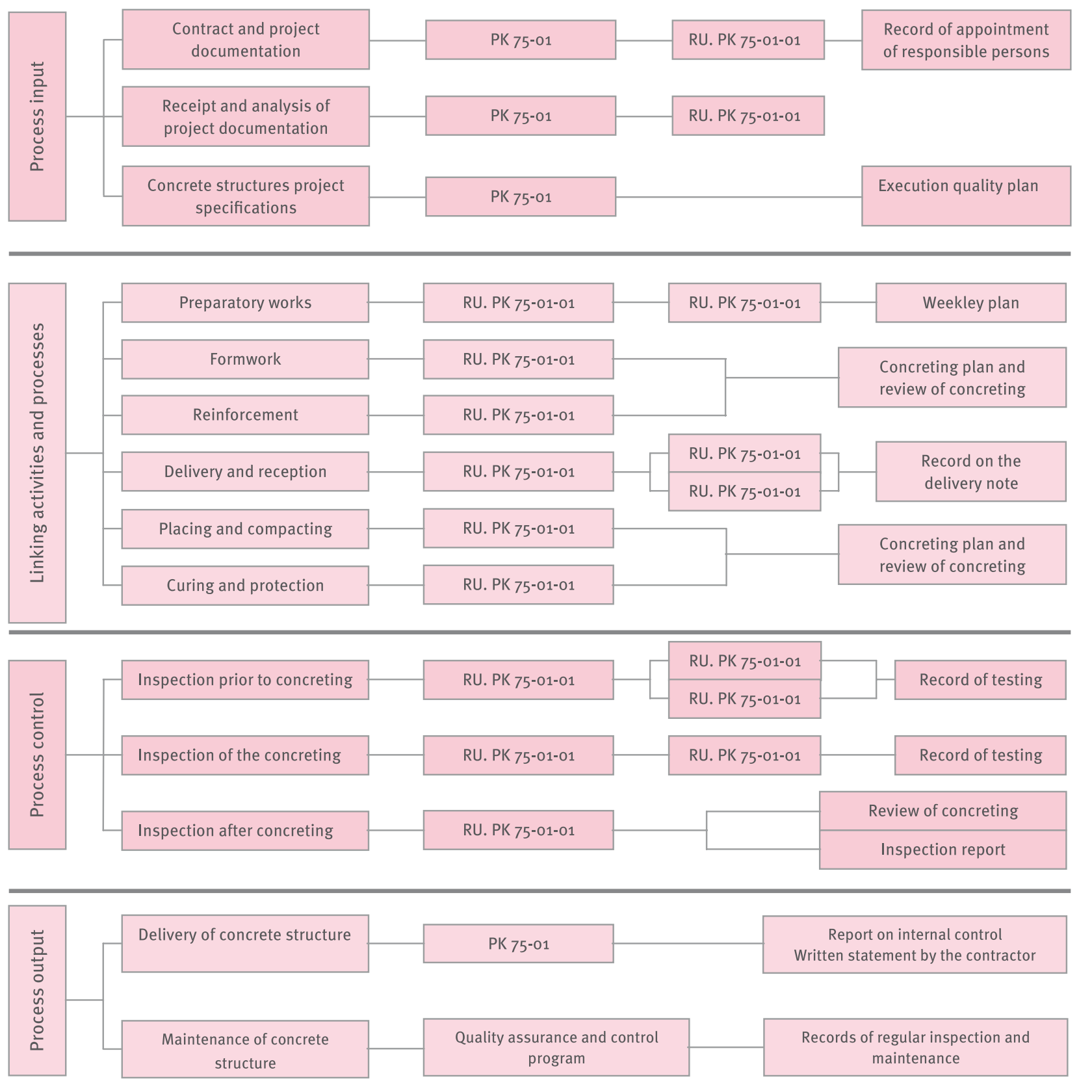

Figure 2: Example of the quality management in the execution of concrete structures

system must continuously be refined and improved, which results in higher efficiency and better results. In order to improve the management system, preventive and corrective actions must be defined.

Data relevant to the implementation of improvements must come from the monitoring of the process as a whole, which includes control and quality assurance in the process of implemen- tation, quality testing of materials at the site and analyzing information received from a client or the supervising engineer. In this way we obtain the information on the suppliers of services and the characteristics of the process that provide the basis for preventive action. Preventive actions are taken in order to eliminate the potential inconsistencies and problems and to prevent their occurrence.
Examples of preventive actions in the process of execution of concrete structures are:

- a detailed review of project documentation

- training of personnel involved in the process

- implementation of safety measures

- the use of safe and quality work equipment

- working with approved suppliers. 


\section{Common errors in execution of concrete structures and ways of improvement}

During the execution of concrete construction, errors occur at all stages. In order to eliminate errors it is necessary to perform the following:

$\checkmark$ a detailed study of project documentation and special requirements of concrete performance

- aligning of the potential doubts before the start of concrete works among the participants in the project (engineer, supervising engineer, site manager)

- establishment of a system of control and quality assurance performance of reinforced concrete structures, including defined duties and responsibilities

- document and define all activities within the process

- defining a way of approving changes in the performance of individual works and the submission of such requests, and specifying the responsible person
- it is necessary to hire professional staff and provide resources for quality management for all activities within the process of performing reinforced concrete works

- appointment of internal monitoring of performance

- planning and providing training for all the participants whose work affects quality

- defining a procedure to eliminate non-compliance performance

- creating a concrete quality

\begin{tabular}{|c|c|c|c|c|}
\hline & $\begin{array}{l}\text { Activity in process of } \\
\text { execution of concrete } \\
\text { structure }\end{array}$ & Reqiurements & $\begin{array}{l}\text { Reference to the } \\
\text { documentation }\end{array}$ & Records \\
\hline 1 & $\begin{array}{l}\text { Reception and analysis of } \\
\text { project documentation }\end{array}$ & $\begin{array}{l}\text { Determining the completeness } \\
\text { and unambiguous design } \\
\text { documentation, HRN EN 13670, } \\
\text { Appendix A }\end{array}$ & $\begin{array}{l}\text { Quality Manual, Quality } \\
\text { Management Procedure - } \\
\text { Execution of building works }\end{array}$ & $\begin{array}{l}\text { Checklist of data that must } \\
\text { be included in the project } \\
\text { specification }\end{array}$ \\
\hline 2 & $\begin{array}{l}\text { Development of operational } \\
\text { plan performance over time } \\
\text { with the necessary resources }\end{array}$ & $\begin{array}{l}\text { Creation of planning, financial, } \\
\text { organizational, technical and } \\
\text { technological preconditions } \\
\text { for the execution of concrete } \\
\text { process performance }\end{array}$ & $\begin{array}{l}\text { Quality Manual, Quality } \\
\text { Management Procedure - } \\
\text { Execution of building works }\end{array}$ & $\begin{array}{l}\text { Plan execution in time, weekly } \\
\text { concreting plan }\end{array}$ \\
\hline 3 & $\begin{array}{l}\text { Development of a concrete } \\
\text { performance quality plan }\end{array}$ & $\begin{array}{l}\text { Definition of control and quality } \\
\text { assurance in all stages of the } \\
\text { process }\end{array}$ & $\begin{array}{l}\text { Program control and quality } \\
\text { assurance - part of the project, } \\
\text { TPBK, HRN EN 206-1, HRN EN } \\
13670\end{array}$ & Quality Plan \\
\hline 4 & Preliminary work & $\begin{array}{l}\text { Site preparation by } \\
\text { organizational scheme and } \\
\text { ensuring all resources for the } \\
\text { process }\end{array}$ & $\begin{array}{l}\text { Concrete performance quality } \\
\text { plan }\end{array}$ & $\begin{array}{l}\text { A checklist of resources, } \\
\text { concreting plan }\end{array}$ \\
\hline 5 & $\begin{array}{l}\text { Erection of scaffolding and } \\
\text { formwork }\end{array}$ & $\begin{array}{l}\text { HRN EN } 13670 \text { Item } 5 \text { and } \\
\text { Appendix B }\end{array}$ & $\begin{array}{l}\text { Operating instructions of the } \\
\text { process - Assembly formwork }\end{array}$ & $\begin{array}{l}\text { Plan and review of performed } \\
\text { concrete (formwork) }\end{array}$ \\
\hline 6 & Assembly reinforcement & $\begin{array}{l}\text { HRN EN } 13670 \text { Item } 6 \text { and } \\
\text { Appendix C }\end{array}$ & $\begin{array}{l}\text { Operating instructions of the } \\
\text { process - Assembly fittings }\end{array}$ & $\begin{array}{l}\text { Plan and review performed } \\
\text { concrete (reinforcement) }\end{array}$ \\
\hline 7 & $\begin{array}{l}\text { Delivery, reception and site } \\
\text { transport of concrete }\end{array}$ & $\begin{array}{l}\text { HRN EN } 13670 \text { Item } 8 \text { and } \\
\text { Appendix E }\end{array}$ & $\begin{array}{l}\text { Operating instructions of the } \\
\text { process - Receiving, handling } \\
\text { and concrete on site }\end{array}$ & $\begin{array}{l}\text { Plan and review of performed } \\
\text { concrete (concrete), concrete } \\
\text { dispatch }\end{array}$ \\
\hline 8 & $\begin{array}{l}\text { Actions to be implemented } \\
\text { prior to concreting }\end{array}$ & $\begin{array}{l}\text { HRN EN } 13670 \text { item } 11 \text { and } \\
\text { Appendix G } \\
\text { Standard family HRN EN } 12350 \\
\text { and HRN EN } 12390\end{array}$ & $\begin{array}{l}\text { Operating instructions of the } \\
\text { process - Monitoring before } \\
\text { and during concreting }\end{array}$ & $\begin{array}{l}\text { Plan and review performed } \\
\text { concreting, the records of } \\
\text { testing of fresh concrete, a } \\
\text { record of making specimens of } \\
\text { concrete }\end{array}$ \\
\hline 9 & $\begin{array}{l}\text { Installation and compaction } \\
\text { of concrete }\end{array}$ & HRN EN 13670 Item 8.4 & $\begin{array}{l}\text { Operating instructions of the } \\
\text { process - Receiving, handling } \\
\text { and concrete on site }\end{array}$ & $\begin{array}{l}\text { Plan and review of performed } \\
\text { concrete (concrete) }\end{array}$ \\
\hline 10 & $\begin{array}{l}\text { Nurturing and protection of } \\
\text { concrete }\end{array}$ & HRN EN 13670 Item 8.5 & $\begin{array}{l}\text { Operating instructions of the } \\
\text { process - Receiving, handling } \\
\text { and concrete on site }\end{array}$ & $\begin{array}{l}\text { Plan and review of performed } \\
\text { concrete (concrete) }\end{array}$ \\
\hline 11 & $\begin{array}{l}\text { Actions to be implemented } \\
\text { after concreting }\end{array}$ & $\begin{array}{l}\text { HRN EN } 13670 \text { Item } 11 \text { and } \\
\text { Appendix G }\end{array}$ & $\begin{array}{l}\text { Operating instructions of the } \\
\text { process - Monitoring after } \\
\text { concreting }\end{array}$ & $\begin{array}{l}\text { Plan and review of performed } \\
\text { concrete (concrete review) }\end{array}$ \\
\hline 12 & $\begin{array}{l}\text { Analysis and preparation of } \\
\text { reports on the procedures of } \\
\text { conformity assessment }\end{array}$ & $\begin{array}{l}\text { Quality Handbook, } \\
\text { TPBK, Article } 29\end{array}$ & $\begin{array}{l}\text { Quality Manual, Quality } \\
\text { Management Procedure - } \\
\text { Execution of building works }\end{array}$ & $\begin{array}{l}\text { Records of quality control } \\
\text { procedures performed, } \\
\text { Report on the procedures of } \\
\text { conformity assessment of } \\
\text { concrete with the project }\end{array}$ \\
\hline
\end{tabular}


performance plan that will elaborate the performance of the construction in accordance with the available resources and organizations.

Corrective actions are implemented in the process after non-conformity has occurred. The same must be carried out based on the records of noncompliance. The responsible person in the process (project manager) must investigate the cause of nonconformities and decide on corrective measures, the way an improvement will be conducted and the period in which they will be removed. Causes of noncompliance must be assessed and those causes should be predicted in the future.

Examples of corrective actions in the process of execution of concrete structures are:

- subsequent testing of compressive strength of concrete

a new calculation of the stability of concrete structures

- concrete repair due to inadequate care and protection

- the adjustment of the geometry of the concrete elements of the designed size

- adjusting the consistency of fresh concrete on site.

\section{Site quality control}

The documentation process of conducting concrete works must be consistent with the requirements of the HRN EN 13670 and the HRN EN ISO 9001 and implemented into the existing quality management system. Proper implementation can be achieved only through the education of all levels of employees. Education is conducted through training semi- nars and workshops. It is essential that those involved in the quality management system are familiar with the scope of powers and responsibilities, such as administration, process carriers and those directly involved in the activities performed. Over time, process performance documents are reviewed and revised to be fully harmonized with the practice. Changes to documents and withdrawal of invalid documents will be conducted in accordance with the procedure for managing the documentation that is defined in the HRN EN ISO 9001.

\section{Conclusion}

All the participants in the construction manage a large number of interdependent processes whose realization requires an elaborated organizational structure, defined processes, ways of their implementation, control and determination of the effectiveness and accountability. Analysis of sources that can cause exceeding deadlines, costs and poor quality in construction projects, shows that there is no clear common strategy and coordinated work of all the participants in construction management when unwanted effects occur.

Well-established business market requires consistently good products' quality and services. In recent years, increased efforts by numerous companies are invested in income producing and survival in a competitive market, requiring significant changes in project management. These changes are most evident in relation to customer/users, suppliers and the quality of products or services. Successful implementation of these changes requires a commitment to quality issues: the process approach, orientation to the buyer/user, and de- velopment of lifelong learning skills of employees.

Execution of concrete operations is a process that consists of a series of controlled and organized activities with start and end dates, that include time, resources, quality and costs. Quality system in this process includes the organizational structure, documentation, activities and resources necessary to meet the requirements of the standard HRN EN 13670 and Annex J of the Technical regulations for concrete structures.

\section{References}

Blanda, M. (2007). Upravljanje kvalitetom pri izvođenju armiranobetonskih

konstrukcija, magistarski rad,

Sveučilište J.J. Strossmayera u Osijeku, Građevinski fakultet, Osijek

Blanda, M.; Dolaček-Alduk, Z.; Mikulić,

D. (2010). Upravljanje kvalitetom kod

izvođenja betonskih konstrukcija,

Građevinar 62: 603-612.

Dolaček-Alduk, Z.; Mikulić, D.; Radujković,

M. (2007). „Upravljanje kvalitetom u

projektno usmjerenom građevinskom

poslovanju.“ Građevinar, 3 (59), 209-

218.

HRN ISO 10006:2002 Upravljanje kvalitetom - Smjernice za kvalitetu u vođenju projekata

HRN EN 13670-1:2006 Execution of concrete structures - Part 1: Common

HRN EN 206-1:2006 Concrete - Part 1: Specification, performance, production and conformity

Radujković, M. (1999). Izvor prekoračenja rokova i proračuna građevinskih projekata, Građevinar 51, 2, 159-165.

Yasamis, F.; Arditi, D.; Mohammadi, J. (2002). „Assessing contractor quality performance.“ Construction Management and Economics 20: 211223. 